\title{
The dinoflagellate cyst genus Polygonifera; emendation and taxonomic stabilization
}

\author{
NARESH C. MEHROTRA \& WILLIAM A. S. SARJEANT \\ K. D. Malaviya Institute of Petroleum Exploration, Oil \& Natural Gas Commission, Dehra Dun, U.P. 248195, India \& \\ Department of Geological Sciences, University of Saskatchewan, Saskatoon, Saskatchewan, Canada S7N 0W0
}

\begin{abstract}
The taxonomic identity of the dinoflagellate cyst genus Polygonifera Habib, 1972 is confirmed, through the recognition of additional morphological characters during the study of specimens from Early-Middle Cretaceous sediments of India. A revised definition of this genus is presented. Leberidocysta Stover \& Evitt, 1978 is considered a subjective junior synonym of Polygonifera and its type species Leberidocysta (ex: Hexagonifera) chlamydata (Cookson \& Eisenack) is transferred to Polygonifera. The other species placed in Leberidocysta are provisionally reattributed to other genera, becoming Craspedodinium (ex: Hexagonifera) defloccata (Davey), Craspedodinium (ex: Palaeostomocystis) pergamentacea (Burger), Hexagonifera laticaudata Vozzhennikova and Hexagonifera scabrata Jain \& Taugourdeau-Lantz. A new species, Polygonifera eisenackii, is described. Morphological differences between the camocavate genera Polygonifera and Dingodinium are clarified.
\end{abstract}

\section{HISTORICAL BACKGROUND}

Cookson \& Eisenack (1961, p. 73) erected the genus Hexagonifera and defined it as "Shell oval, wall of variable thickness, smooth or ornamented. Pylome formed by the removal of a 6 -sided lid at one pole." They placed two species into this genus: $H$. glabra (Pl. 12. figs. 9-13, p. 74) and $H$. vermiculata (pl. 12 , figs. 6-8, p. 74), the former being selected as the type. H. glabra was described thus: "Shell thick walled, smooth, homogeneous, occasionally perforated by straight narrow pores. Lid 6-sided, usually with 3 short and 3 long sides in alternation." A little later these authors emended the genus to include cavate forms and described a third species, $\boldsymbol{H}$. chlamydata (Cookson \& Eisenack, 1962, p. 496, pl. 7, figs. 1-3, 5-8). This species is characterised by its thick endophragm, having a verrucose ornamentation, and its thinner, smooth periphragm.

Habib (1972, p. 376) erected the genus Polygonifera for camocavate dinoflagellate cysts with an apical archaeopyle and a polygonal to oval ambitus, naming Polygonifera evittii as type species. This is characterised by its distinct cingulum and scabrate to granulose cyst ornamentation (ibid., pl. 5, figs. 1-2). Habib distinguished Polygonifera from Hexagonifera on the basis of presence of a "distinct" cingulum in Polygonifera, a character not observed in Hexagonifera.

Lentin \& Williams (1976, p. 84), in their monograph on fossil peridinioid dinocysts, discussed the archaeopyle types in the various species assigned to Hexagonifera by Cookson \& Eisenack $(1961,1962)$. The archaeopyle type in $H$. glabra was interpreted as intercalary, of hexa 2a type. Further, they doubted the generic assignment of Hexagonifera chlamydata, since the nature of the archaeopyle in the illustrations of Cookson \& Eisenack (1962, p. 496, pl. 7, figs. 1-3, 5-8) appeared to be apical. However, they retained this species in Hexagonifera, pending confirmation of its having an apical archaeopyle.

Stover \& Evitt (1978, p. 107-108), in their general analysis of fossil dinoflagellates, emended the genus Hexagonifera to include only proximate cysts having an intercalary archaeopyle, a character seen only in the type species $H$. glabra. The character of archaeopyle in Hexagonifera chlamydata was confirmed as apical (ibid., p. 60). This interpretation is fully acceptable to us, for not only do the illustrations of Cookson \& Eisenack (1962, pl. 7, figs. 1-3, 5-8) clearly suggest an apical archaeopyle in this species but also our examination of a colour transparency of the holotype (No. 123 in the series prepared for sale by Helby \& Partridge, 1980) supports their conclusion. A cavate genus, Leberidocysta, was proposed by Stover \& Evitt (ibid.,p. 59-60) for cavate cysts having an apical archaeopyle, Leberidocysta chlamydata (Cookson \& Eisenack) being selected as its type species.

Stover \& Evitt $(1978$, p. 75$)$ suggested further that Polygonifera might prove to be a junior synonym of Dingodinium Cookson \& Eisenack, 1958, noting the similarity in the nature of their cyst cavation (camocavate). They added that the archaeopyle type in Dingodinium and the possible presence of an apical horn in Polygonifera needed to be determined, to test this hypothesis.

\section{MORPHOLOGY OF THE POLYGONIFERA- LEBERIDOCYSTA GROUP}

In our study of Early-Middle Cretaceous subsurface sediments of Perivadavadi shallow well-1, Cauvery 
basin, south India, a large number of well preserved specimens were encountered resembling Polygonifera and the type species of Leberidocysta, L. chlamydata, in shape, nature of cyst cavation and archaeopyle characters. Specimens with operculum detached were most commonly observed, though individuals with an attached operculum were not rare. The archaeopyle, as observed in Polygonifera and in the type species of Leberidocysta, $L$. chlamydata, is definitely apical.

Preservation of specimens in different orientations results in an apparently variable degree of pericoel development. The frequent folding of the periphragm and its degree of preservation, together with variable cyst flattening, makes the morphology of these dinocysts appear unduly complex. Nevertheless, this provides an excellent opportunity to study their morphological characteristics in greater detail. Our observations are:

\section{Shape}

Specimens, when orientated in dorsoventral position, exhibit generally a polygonal to subpolygonal (Figs. 2a, b, 3a) or even oval (Figs. 1a, 3b) periblast and an oval endoblast. In lateral compressions, both periblast and endoblast appear oval (Figs. 1b, c, 2c). Similar observations were made by Habib (1972, p. 376), when describing the type species $P$. evittii. No apical horn is seen, though a small "notch" or mamelon may appear to be present on the apical region, due to periphragm folding (Fig. 1b).

\section{Cavation}

The cyst is camocavate. The apparent degree of pericoel development is greatly affected by periphragm preservation (being delicate, it is often torn or incompletely preserved) and folding. The pericoel may be well developed (Figs. 1b, c, 2a, b, c, 3a, b) or only partially developed (Figs. 1a, d). In many cases the periphragm may not be preserved at all, or may be apparently developed only in the antapical region (Pl. 2, fig. 6).

Stover \& Evitt (1978, p. 75), analysing the genus Polygonifera on the basis of published illustrations of its type species $P$. evittii, concluded that the periblast remained attached to the endoblast along the dorsal surface only. Our own observations agree with this. However, in view of the absence of either a clear sulcal notch or parasutural features, our interpretation, and also the orientation of specimens illustrated in this study, cannot be considered conclusively established. Regarding the orientation of the specimens of Polygonifera examined in the present study, we believe them to be most commonly preserved either in slightly oblique dorsal (Figs. 2a, b, 3a, b) or ventral views (Fig. 2), though lateral compressions are also not uncommon (Figs. 1b, c, d, 2c).

\section{Archaeopyle}

The archaeopyle is formed by the loss of all the paraplates of the apical series, these being removed as a simple operculum. The number of paraplates appears to be four, as suggested by the occasional partial development of accessory archaeopyle sutures (Figs. 1a; PI. 2, fig. 4). Rarely, only the anterior piece of the operculum on the ventral surface is lost in archaeopyle development, the dorsal section remaining attached (Fig. 1b; Pl. 2, fig. 7).

The archaeopyle margin is usually zigzag. Habib (1972, p. 376), studying this feature in $P$. evittii, considered a sulcal notch and six precingular paraplates to be indicated (ibid., pl. 5, figs. 1,2). Though a sulcal notch could not be unequivocally recognised in any specimen in the present assemblage, its possible position is suggested in a few (see Fig. 1a; Pl. 2, figs. 4, 6). The character of the archaeopyle in the Indian specimens is not sufficiently clear for us to determine with confidence the number of precingular paraplates.

Specimens are most often found with their operculum detached. In this case, both peripyle and endopyle can be clearly distinguished (Figs. 1a, 2a, b, 3a, b; Pl. 1, figs. 1, $2,5,7)$. Specimens with an attached operculum are also not rare. In such instances both perioperculum and endoperculum are usually distinguishable (Figs. 1c, 2c; Pl. 1, figs. 3, 4, 6; Pl. 2, fig. 5). In a few cases the perioperculum is free, while the endoperculum remains attached (Fig. 1d; Pl. 2, figs. 2, 3).

\section{Paratabulation}

Parasutural features are usually not well developed. However, one species assigned to this genus does exhibit a fairly full paratabulation. This is Polygonifera (ex: Meiourogonyaulax) staffinensis (Gitmez, 1973, p. 276-278, pl. 3, fig. 2; text-fig. 20) Davey, 1982, p. 31, which reflects the paratabulation: ?', ?0a, 6", 6c, 6"', $2 \mathrm{p}, 1 \mathrm{pv}, 1^{\prime \prime \prime \prime}$, either by means of elevated crests on a murochorate central body, as interpreted by Gitmez herself (op. cit.) or by crests on the endoblast of a camocavate cyst, as seems to be Davey's interpretation. The latter, more recent conclusion is here accepted as correct for purposes of discussion; however, Davey's re-interpretations of the morphology of this species is unsupported by illustrations and must be considered unproven, pending a re-examination of the holotype.

\section{Claustrum}

A small, regularly or irregularly shaped opening of variable size, corresponding to a claustrum (see Norris, 1978 ), may be present on the hypocyst. Its position is variable; it may be situated just below the cingulum (Fig. 1b) or close to the antapex (Fig. 1c). Its irregularity of shape and position casts some doubt upon this being a preformed opening; the possibility of its being the work of a scavenger or predator cannot be excluded. 


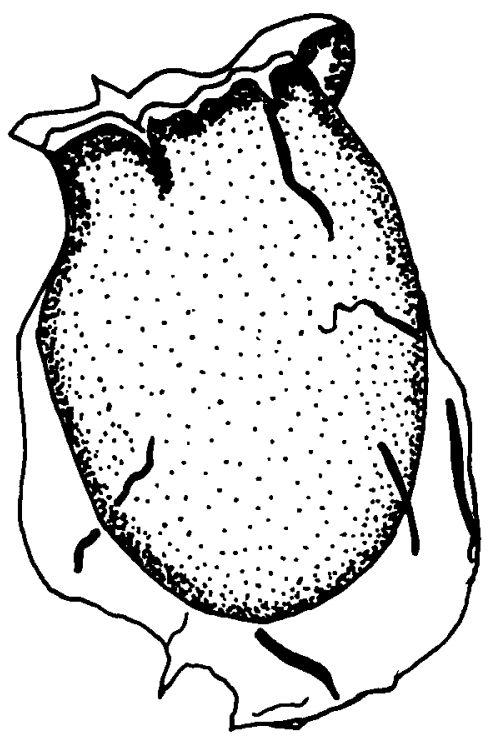

a

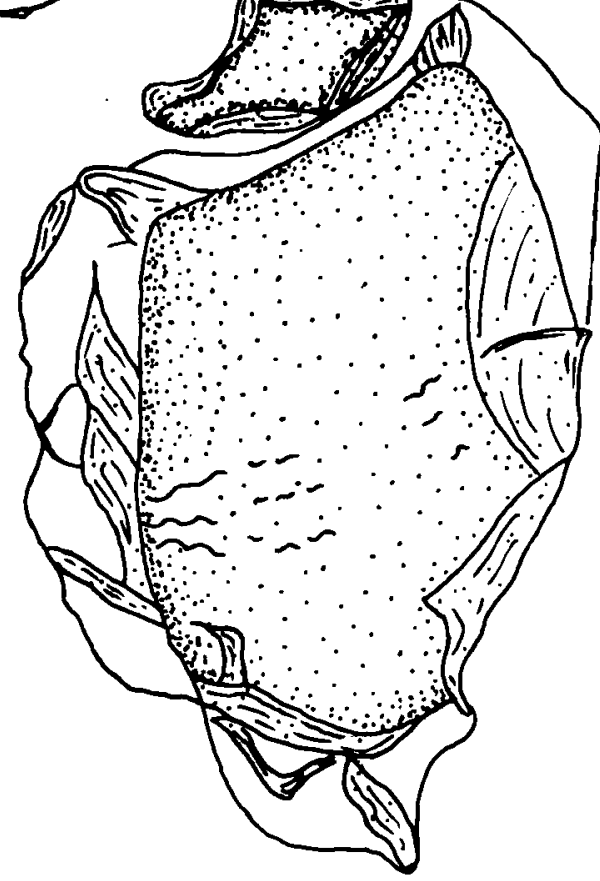

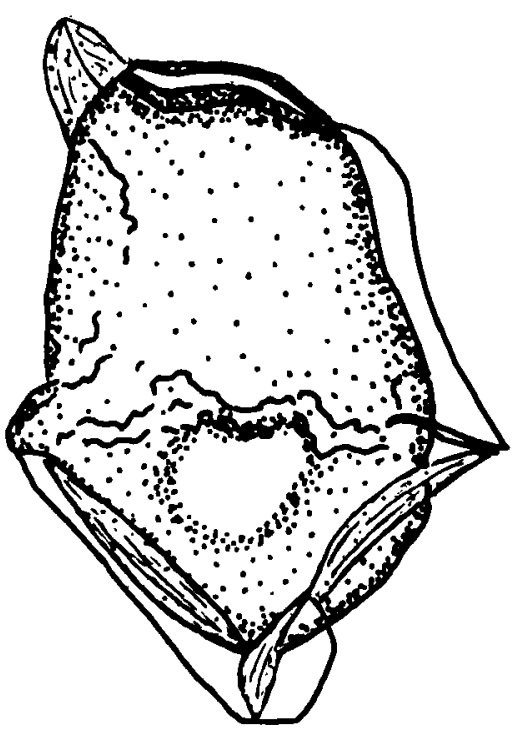

b

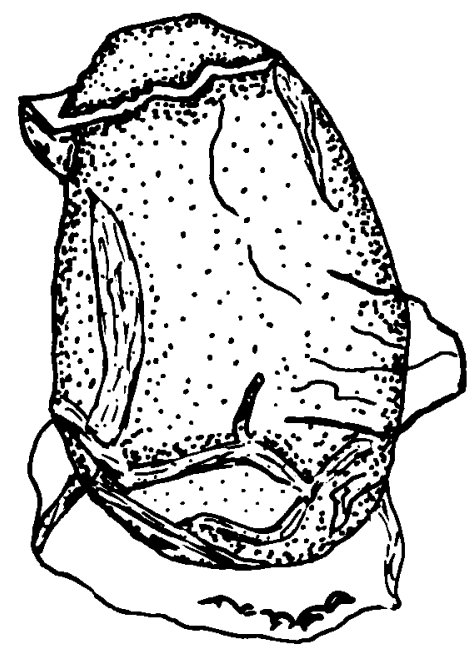

d

Fig. 1. Polygonifera eisenackii sp. nov.

a. Slide IPEP/PVD/31/5 (108-110 m); paratype a in ventral view; note accessory archaeopyle parasutures. (See also Pl. 2, fig. 4).

b. Slide IPEP/PVD/31/4 (108-110 m); specimen in left lateral view; note position of cingulum, claustrum as seen below the cingulum on the hypotract and an apical mamelon formed by the periphragm folding. It appears that the archaeopyle is formed by the loss of only anterior part of the operculum on the ventral surface, part of the operculum on the dorsal surface remaining attached. (See also P1. 2, fig. 7).

c. Slide IPEP/PVD /25/4 (95-97 m); holotype in oblique lateral view. Note the position of the cingulum, as indicated by periphragm folding, and the attached endoperculum and perioperculum. (See also Pl. 1, fig. 6).

d. Slide IPEP/PVD/31/4 (108-110 m); specimen in left lateral view. Note the attached endoperculum and free perioperculum, the periphragm folding and the position of the cingulum on the cyst margin. (See also Pl. 2, fig. 3).

[In all the figures, the shading is to clarify the character of archaeopyle and cyst cavation. It does not suggest cyst ornamentation]. 


\section{Cingulum}

The presence of a cingulum has been noted frequently in Indian specimens, though the degree of its development is variable. Folding of the periphragm may indicate either:

1) a distinct and well developed cingulum (P1. 1, figs. $1-5,7$; Pl. 2, fig. 7 ; see also Figs. 1b, 2b, 3a-b);

2) a faint or incomplete cingulum (P1. 1, fig. 6; Pl. 2, figs. 1-3, 5; see also Figs. 1c, $2 \mathrm{a}, \mathrm{c})$, or

3 ) the cingulum may not be visible at all ( $\mathrm{Pl}$. 2, figs. 4, 6; see also Fig. 1a).

The cingulum, when completely developed, occupies the maximum width of the cyst body (a feature observed also by Habib, 1972, p. 376). It divides the cyst into a large epitract and a smaller hypotract.

To overcome present problems in establishing the taxonomic identity of these dinocysts, it is necessary to recognise that the degree of development of the cingulum in Polygonifera is a variable, and not a constant, character, unsuitable as a means for generic separation. In consequence, we consider that the genus Leberidocysta, differentiated only on this character, should not be maintained and that its type species, $L$. (ex:Hexagonifera) chlamydata, should be transferred to Polygonifera.

The other species attributed to Leberidocysta by Stover \& Evitt (1978, p. 60) do not exhibit the morphological characters of Polygonifera; they are discussed later.

\section{Sulcus}

This feature is not usually developed, its position being suggested only by the sulcal notch. Only in Polygonifera staffinensis (Gitmez) is the sulcus relatively readily discernible. However, as noted earlier, we have reservations concerning the allocation of that species to this genus.

\section{SYSTEMATIC DESCRIPTIONS}

Order Peridiniales Haeckel

Suborder Hystrichosphaeridiineae Norris, 1978

Family Senoniasphaeraceae Norris, 1978

Genus Polygonifera Habib, 1972, emend.

Leberidocysta Stover \& Evitt, 1978

Type species. Polygonifera evittii Habib, 1972, p. 376, pl. 5, figs. 1, 2. Late Jurassic (Oxfordian-Kimmeridgian). Emended diagnosis. Cysts camocavate, generally of intermediate to large size. Endoblast oval to ellipsoidal; periblast polygonal to oval. Apical horn lacking. Periphragm thin, delicate, frequently folded; endophragm comparatively thicker. Endoblast separated from periblast everywhere except on one side (?dorsal). The apparent size of the pericoel is largely a consequence of the degree of periphragm folding and preservation. Parasutural features usually not developed. When determinable, the paratabulation may be: $4^{\prime}, ? 0 \mathrm{a}, 6^{\prime \prime}, 6 \mathrm{c}$, $6^{\prime \prime \prime}, 1-2 \mathrm{p}, 1 \mathrm{pv}, 1^{\prime \prime \prime}$. Endophragm smooth or ornamented with features of low to moderate relief; ornamentation may be of verrucose, granulose, reticulate, scabrate or punctate type. Periphragm generally smooth or faintly ornamented (reticulate, punctate or scabrate). Archaeopyle apical, type (4a); operculum may be free or attached. Cingulum feebly to clearly indicated; when clearly developed, it occupies the maximum cyst width. Sulcus generally not developed, indicated by a sulcal notch only. A claustrum may be present in the hypotract.

General archaeopyle formula: (4a)/(4a); after Evitt (1967), Lentin \& Williams (1976) and Norris (1978).

\section{Polygonifera eisenackii sp. nov.}

(Pl. 1, figs. 1-7; Pl. 2, figs. 1-7; Figs. 1a-d, 2a-c, 3a-b) Derivation of name. In honour of the late Prof. Alfred Eisenack.

Diagnosis. Cyst proximate, camocavate. Periblast polygonal-subpolygonal or oval in ambitus, oval in lateral view; endoblast oval to broadly ellipsoidal. Apical horn lacking; a small notch may develop in the apical region, due to periphragm folding. Periphragm thin, delicate; it may be fully, partially or not at all developed and, when present, is typically folded. Endophragm relatively thicker and typically not distorted. Both endophragm and periphragm are smooth or weakly ornamented (reticulate, foveoreticulate, or finely punctate). No parasutural features are present. Archaeopyle apical, (4a)/(4a); peripyle and endopyle are usually distinct. Operculum free or attached. Cingulum indicated by periphragm folding, sometimes distinct and completely developed, in other instances faintly, incompletely or not at all suggested. Typically, no indication of a sulcus is seen other than a poorly marked sulcal notch. A claustrum of variable size and shape may be present in the hypotract.

Holotype. Slide IPEP/PVD/25/4, Pl. 1, fig. 6; Fig. 1c. Material. Paratype a. Slide IPEP/PVD/31/5, Pl. 2, fig. 4; Fig. 1a; paratype b. Slide IPEP/PVD/25/4, P1. 2, fig. 1; Fig. 2a. The holotype, paratypes and all illustrated specimens are deposited in the K. D. Malaviya Institute of Petroleum Exploration, Dehra Dun, India. Supplementary material is lodged in the palynological collections of the University of Saskatchewan, Saskatoon, Canada. Locality and horizon. Perivadavadi shallow well-1, Cauvery basin, South India (for holotype and both paratypes). Holotype and paratype $b$ are from a claystone bed at depth 94-96m (Core 25), Middle Cretaceous (Aptian); paratype 2 is from a claystone bed at depth 108-110 m (Core 31), Middle Cretaceous (Aptian).

Dimensions. Holotype (operculum attached); periblast $89 \times 50 \mu \mathrm{m}$; endoblast $68 \times 39 \mu \mathrm{m}$. Paratype a (operculum attached); periblast $55 \times 40 \mu \mathrm{m}$; endoblast $45 \times 32 \mu \mathrm{m}$. Paratype b (operculum attached); periblast 


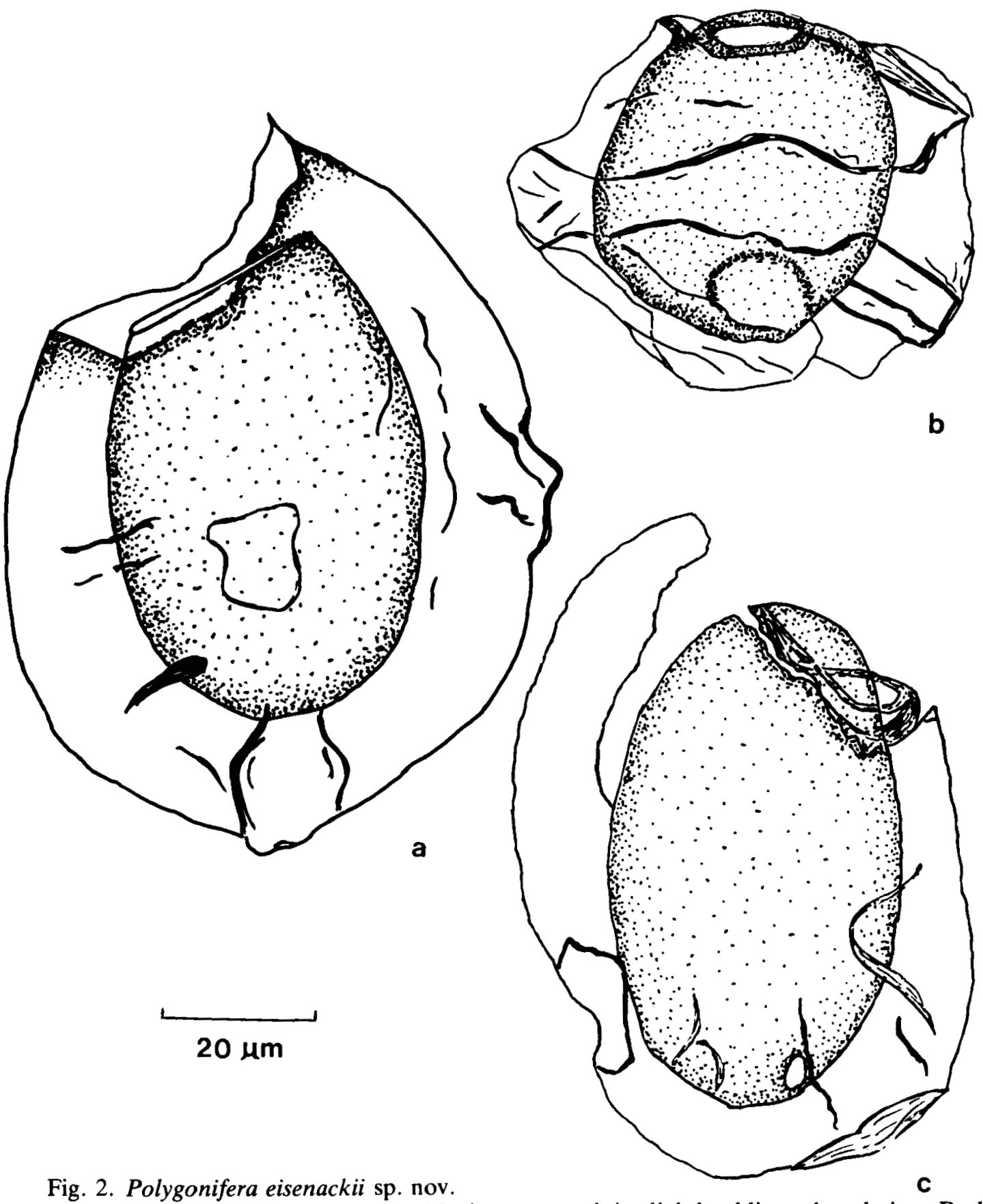

a. Slide IPEP/PVD/25/4 $(95-95 \mathrm{~m})$; paratype $b$ in slightly oblique dorsal view. Both peripyle and endopyle are distinct and a cingulum faintly indicated along the cyst margin by periphragm folding. Note the subpolygonal outline of the periblast. (See also Pl. 2, fig. 1).

b. Slide IPEP/PVD/37/5 (122-124 m); specimen in dorsal view. Note the peripyle and endopyle, the position of the cingulum (as indicated by periphragm folding) and the subpolygonal outline of the periblast. (See also PI. 1, figs. 1,2).

c. Slide IPEP/PVD/25/4 (95-97 m); specimen in (?) oblique lateral view. Both endoperculum and perioperculum are attached, but part of the periblast in the apical region is damaged. Note the indication of the cingulum on the cyst margin and a small opening in the hypotract. (See also Pl. 2, fig. 5).

[In all the figures, the shading is to clarify the character of archaeopyle and cyst cavation. It does not suggest cyst ornamentation]. 
$92 \times 63 \mu \mathrm{m}$; endoblast $61 \times 45 \mu \mathrm{m}$. Range (operculum free); periblast $50 \times 48 \mu \mathrm{m}$ to $92 \times 73 \mu \mathrm{m}$, endoblast $40 \times 35$ to $61 \times 45 \mu \mathrm{m}$. A single specimen (Pl. 2, fig. 6) measured with periblast partially developed, endoblast complete with attached operculum; endoblast $42 \times 37 \mu \mathrm{m}$. Remarks. This species is readily distinguishable from $P$. evittii and $P$. (ex: Hexagonifera) chlamydata by its laevigate to weakly ornamented endoblast. The endoblast ornamentation in $P$. evittii is scabrate to granulose and that in $P$. chlamydata is verrucose. The degree of development of the cingulum is variable in $P$. eisenackii, whereas the cingulum is well developed in $P$. evittii (Habib, 1972, pl. 5, figs. 1, 2) and not developed at all in $P$. chlamydata (Cookson \& Eisenack, 1962, pl. 7, figs. 1-3, 5-8.).

Polygonifera eisenackii exhibits a broad size range. The holotype selected is a complete specimen with attached operculum and measures $89 \mu \mathrm{m}$ (overall length). The two paratypes ( $a$ and $b$ ) have been selected to demonstrate the marked variation in size exhibited by this species. They represent extremes in their range, the overall length of paratype a being only $55 \mu \mathrm{m}$ (operculum free) whereas paratype b attains $92 \mu \mathrm{m}$. It is conceivable that future studies may favour the subdivision of this species into two subspecies, based mainly on this difference in size.

Habib (1972, p. 376) gave the size range of the type species $P$. evittii as $42-62 \mu \mathrm{m}$, as measured on twelve specimens. It was, however, not indicated whether the specimens measured were complete or with detached operculum. Since the specimens from India, described above, are intermediate to large in size, we prefer to recognise the size range in Polygonifera as intermediate to large, and not small to intermediate as described by Stover \& Evitt (1978, p. 75). Other species of Polygonifera:
Polygonifera chlamydata (Cookson \& Eisenack, 1962, p. 496, pl. 7, figs. 1-3, 5-8) comb. nov., Middle-Late Cretaceous (Albian-Cenomanian). [Formerly Hexagonifera and Leberidocysta.]

Polygonifera staffinensis (Gitmez, 1970, p. 276-278, pl. 3, fig. 1; text-figs. 20a-b) Davey, 1982, p. 31. Upper Jurassic (Kimmeridgian). [Formerly Meiourogonyaulax. ]

\section{OTHER SPECIES FORMERLY PLACED IN LEBERIDOCYSTA}

Leberidocysta defloccata (Davey \& Verdier, 1973, p. 198, pl. 3, figs. 6, 8) was described as closely resembling Hexagonifera chlamydata (assigned herein to Polygonifera) in its overall appearance but differing in having a smooth inner body. A comparison of the photographs of the holotype of Davey \& Verdier's species $(1973$, pl. 3 , fig. 8) and that of Hexagonifera chlamydata (Cookson \& Eisenack, 1962, pl. 7, fig. 2) reveals marked dissimilarities in their morphological characters. The former has a spherical endoblast and a roughly subspherical periblast, while the latter is characterised by having an oval endoblast and subpolygonal periblast. There is a marked difference in the size of endoblast and periblast in Davey \& Verdier's specimen, while this is not the case in Polygonifera (ex: Hexagonifera) chlamydata. Further, whereas Polygonifera chlamydata is camocavate, this character is not obvious in Hexagonifera defloccata. Recognising these characters, we do not feel it proper to place Davey \& Verdier's forms in Polygonifera. The precise placement of this species (previous assignments were to Hexagonifera Davey \& Verdier, 1973, p. 198, pl. 3, figs. 6, 8; Thalassiphora Lentin \& Williams, 1976, p. 85; and Leberidocysta Stover \& Evitt, 1978,p. 60) can probably be best determined by re-examination of its type

\section{Explanation of Plate 1 \\ All figures are $\times 1024$ \\ Polygonifera eisenackii sp. nov.}

Figs. 1, 2. Slide IPEP/PVD/37/5 (122-124 m): fig. 1, dorsal surface; fig. 2, ventral surface, by transparency. (For details see Fig. 2b).

Figs. 3, 4. Slide IPEP/PVD/31/1 (108-110 m); specimen in lateral view: fig. 3, upper surface; fig. 4; lower surface, by transparency. Note position of cingulum and the perioperculum and endoperculum, both attached.

Fig. 5. Slide IPEP/PVD/25/4 (95-97 m); specimen in (?) slightly oblique dorsal view. (For details see Fig. 3b).

Fig. 6. Slide IPEP/PVD/25/4 (95-97 m); holotype in oblique lateral view. (For details see Fig. 1c).

Fig. 7. Slide IPEP/PVD/25/4 (95-96 m); specimen in (?) dorsal view. (For details see Fig. 3a). 

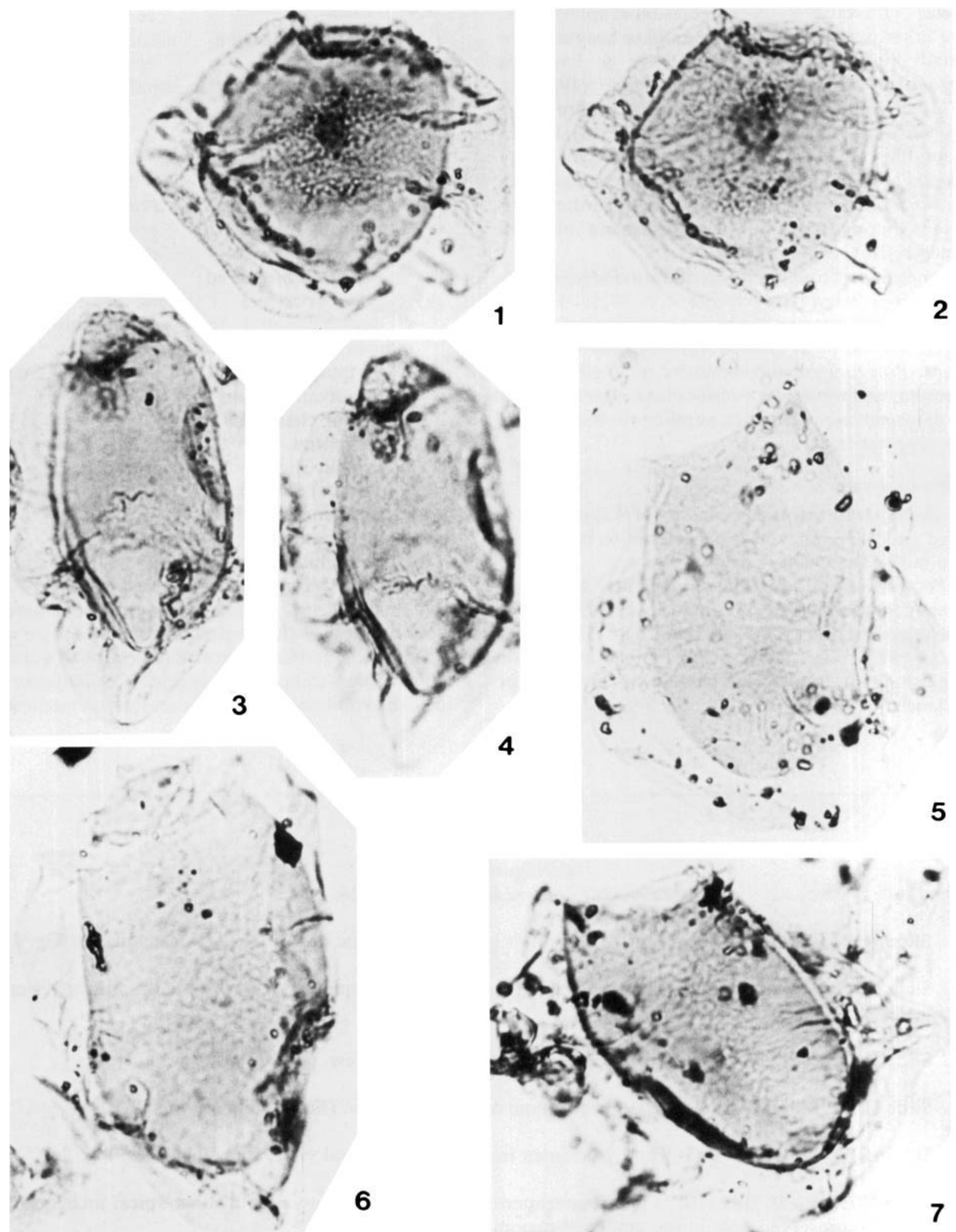

1
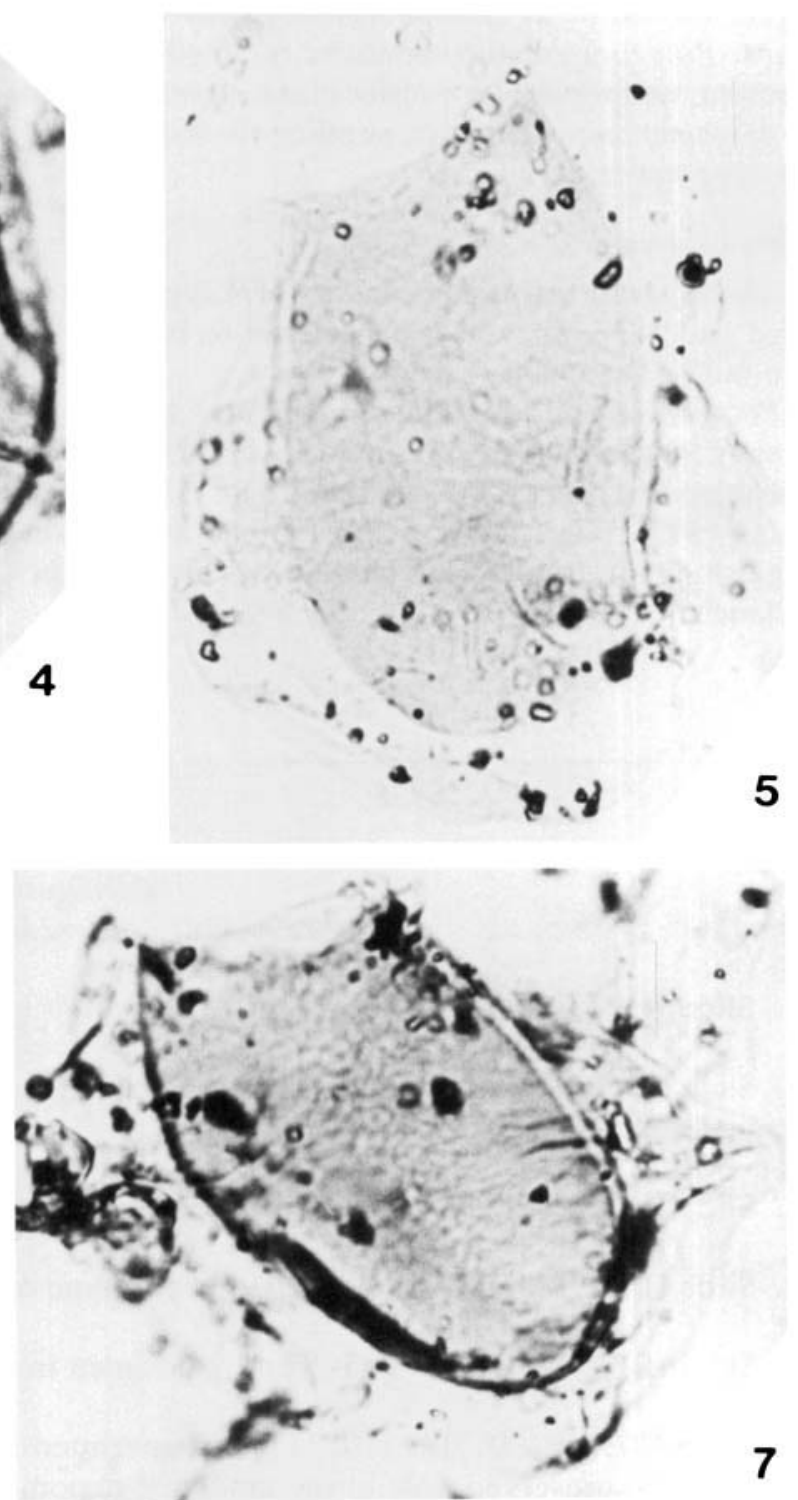
material. For the moment its reassignment to the genus Craspedodinium Cookson \& Eisenack, 1974, as C. defloccata (Davey \& Verdier) seems most appropriate.

The other two species of Hexagonifera assigned provisionally to Leberidocysta by Stover \& Evitt are Hexagonifera laticaudata Vozzhennikova (1967, p. 125-126, pl. 54, fig. 1) and Hexagonifera scabrata Jain \& Taugourdeau-Lantz (1973,p. 64, figs. 11, 12). In view of poor illustrations and descriptions, which do not enable the determination of archaeopyle character, we are not in a position to suggest anything regarding their precise taxonomic identity; these species are therefore returned to Hexagonifera.

The species described by Burger, first as Palaeostomocystis pergamentacea (Burger, 1980a, p. 88, pl. 47, figs. $2,3)$ and a little later as ?Leberidocysta pergamentacea (Burger, 1980b, p. 272) is morphologically very dissimilar to Polygonifera and cannot be retained in it. For the present, we propose its transfer into Craspedodinium as $C$. pergamentacea (Burger), pending re-examination of the type material.

\section{CONCLUSIONS}

1) The separate taxonomic identity of Polygonifera is stressed and Leberidocysta is considered to be its subjective junior synonym.

2) Polygonifera and Dingodinium are two very different genera which exhibit similarity in characters of cyst cavation and general size and shape only (Mehrota \& Sarjeant, Ms). The table below summarises their distinguishing morphological characters, in order of importance.
Polygonifera
(i) archaeopyle - apical
(ii) apical horn - lacking
(iii) cingulum - generally weakly, less commonly well developed
(iv) periphragm very delicate in nature typically folded; fully, partially or not at all preserved
(v) degree of pericoel development greatly affected by periphragm preservation and folding characters
(vi) dorsoventral (usually slightly oblique) flattening more common than the lateral
Dingodinium
variable, intercalary or combination usually present and well developed usually well developed
less delicate than in Polygonifera and generally well developed
pericoel development not significantly affected by periphragm preservation and folding
lateral flattening most common

3) The complete and distinctive development of the cingulum in Oxfordian-Kimmeridgian species $P$. evittii and $P$. staffinensis (Kimmeridgian), its comparatively weak and less distinct representation in Aptian species $P$. eisenackii, and the lack of an indication of a cingulum in the Albian-Cenomanian species $P$. chlamydata seems to be of evolutionary significance. Further studies in this

Explanation of Plate 2

All figures are $\times 960$

Polygonifera eisenackii sp. nov.

Fig. 1. Slide IPEP/PVD/25/4 (95-97 m); paratype b in slightly oblique dorsal view. (For details see Fig. 2a).

Fig. 2. Slide IPEP/PVD/31/3 (108-110 m); specimen in (?) slightly oblique dorsal view. Note the attached operculum and subpolygonal periblast.

Fig. 3. Slide IPEP/PVD/31/4 (108-110 m); specimen in left lateral view. (For details see Fig. 1d).

Fig. 4. Slide IPEP/PVD/31/5 $(108-110 \mathrm{~m})$; paratype a in ventral view. (For details see Fig. 1a).

Fig. 5. Slide IPEP/PVD/25/4 (95-97 m); specimen in (?) oblique lateral view. (For details see Fig. 2c).

Fig. 6. Slide IPEP/PVD/31/5 $(108-110 \mathrm{~m})$; specimen in ventral view, showing a distinct apical archaeopyle and periphragm preserved only in the antapical region.

Fig. 7. Slide IPEP/PVD/31/4 (108-110 m); specimen in left lateral view. (For details see Fig. 1b). 


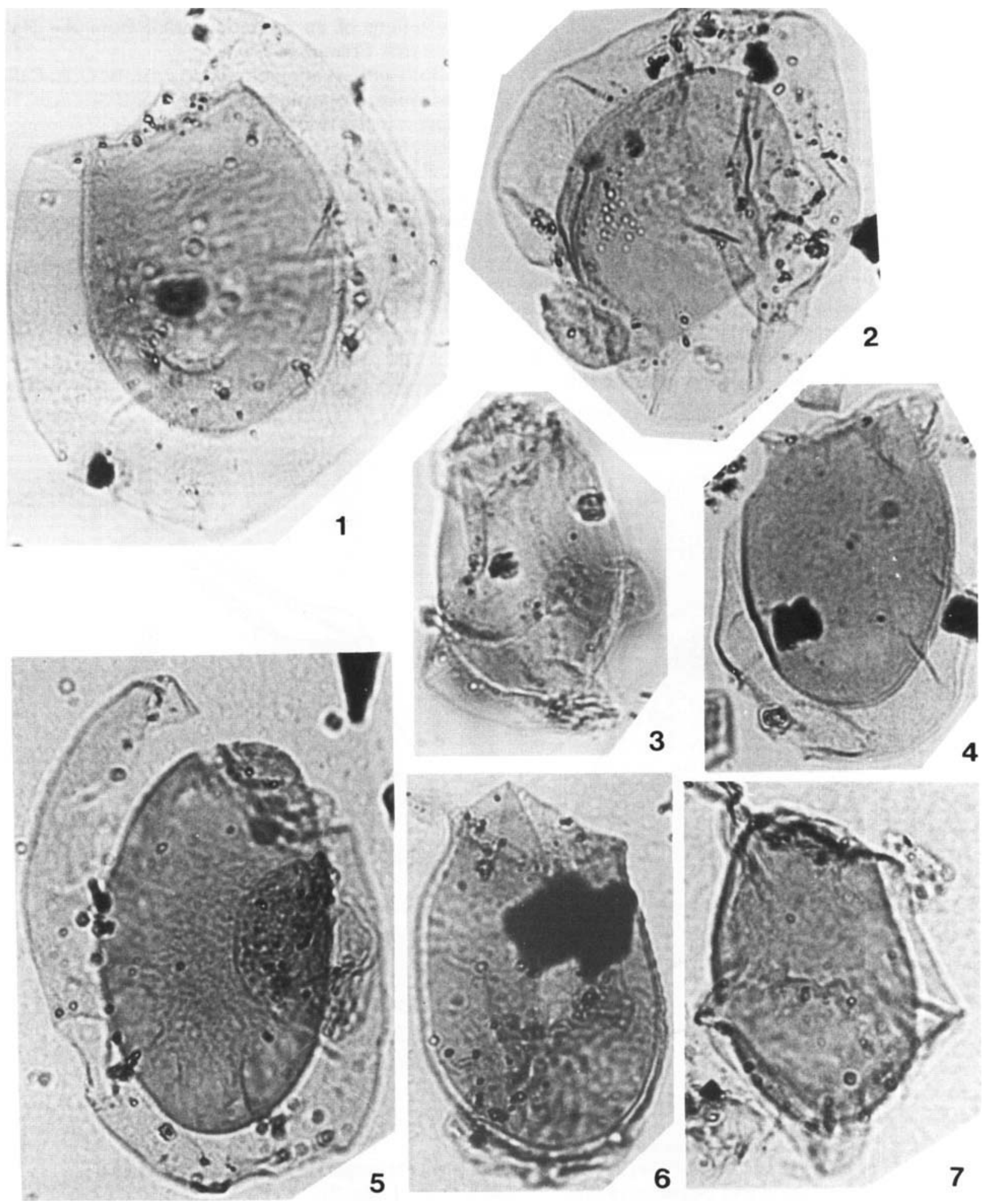


direction are needed to elucidate this biological phenomenon.

\section{ACKNOWLEDGEMENTS}

N. C. Mehrotra would like to express his gratitude to the Government of India for financing his visit to Canada under a post-doctoral National Scholarship Scheme. He is grateful also to Mr. S. P. Wahi (Chairman), Mr. S. N. Talukdar (Member Exploration), Mr. L. L. Bhandari (Director, K. D. Malaviya Institute of Petroleum Exploration) Oil and Natural Gas Commission, Dehra Dun, India for deputing him to the University of Saskatchewan and to Dr. S. K. Biswas (Dy. General Manager), Mr. V. Raiverman (Chief Geologist) and Dr. B.S. Venkatachala (Suptdg. Palynologist) for their support and keen interest in this research. This author is especially grateful to Drs. Biswas and Venkatachala for their advice and help in various ways to make this col- laboration possible. Permission of O.N.G.C. for publishing this research work is gratefully acknowledged.

The work of W.A.S. Sarjeant was undertaken during the tenure of an operating grant from the National Research Council of Canada.

Both authors are indebted to Prof. W.G. E. Caldwell, Chairman, Department of Geological Sciences, for his support in this research, to Ms. Dagmar Pearson and Ms. Linda Krukewich (Research assistants to W.A.S.S.) for their assistance in preparation of the manuscript and to the Audiovisual Services and Engineering Photographic Services, University of Saskatchewan, for photographic work.

The views expressed in this publication are those of the authors and not necessarily of O.N.G.C.

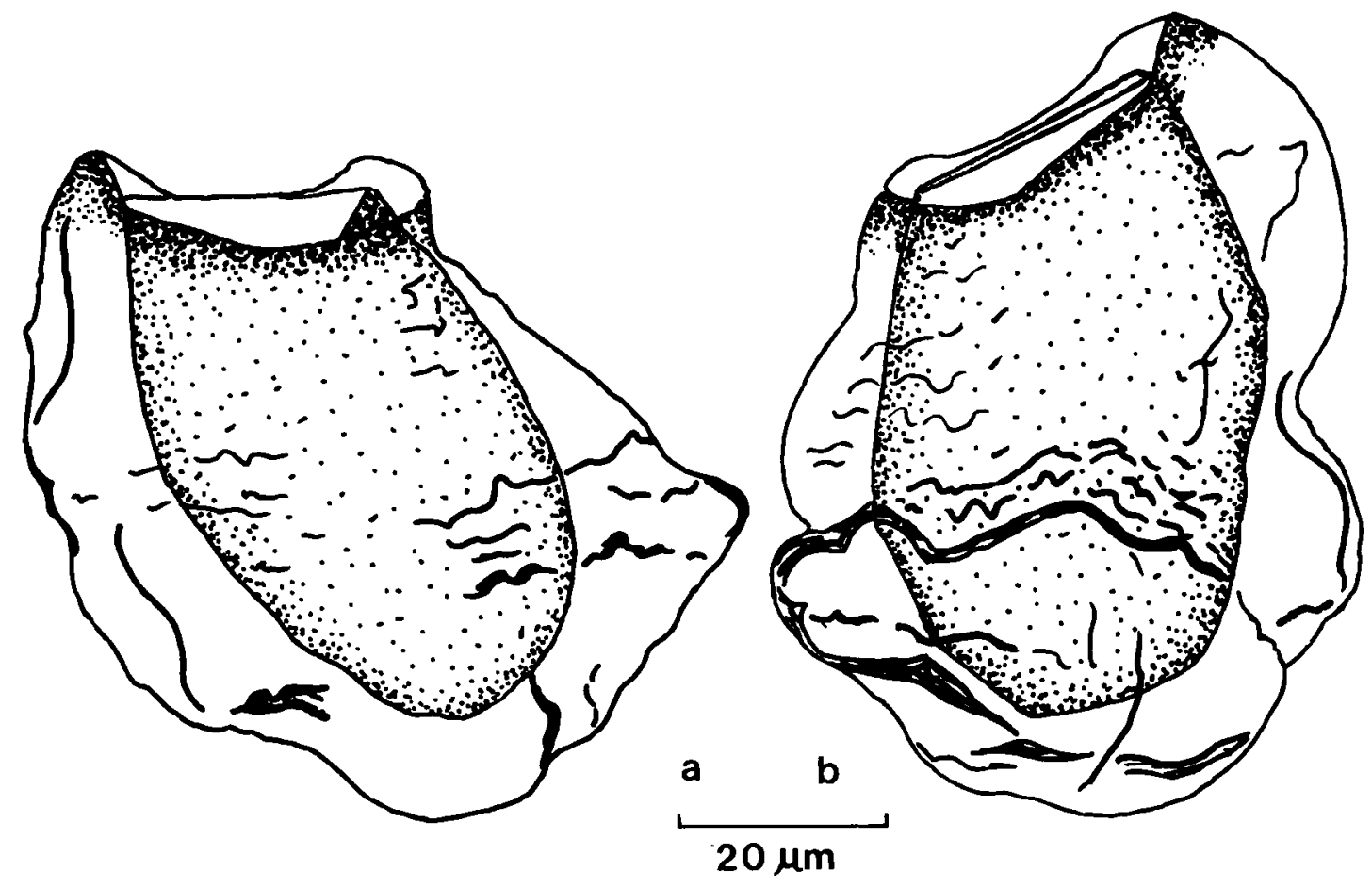

Fig. 3. Polygonifera eisenackii sp. nov.

a. Slide IPEP/PVD/25/4 (95-97 m); specimen in (?) dorsal view, showing the peripyle, endopyle and cingulum distinctly. (See also Pl. 1, fig. 7).

b. Slide IPEP/PVD/25/4 (95-97 m); specimen in (?) slightly oblique dorsal view. Note the distinct cingulum and the peripyle and endopyle. (See also Pl. 1, fig. 5).

[In all the figures, the shading is to clarify the character of archaeopyle and cyst cavation.

It does not suggest cyst ornamentation]. 


\section{REFERENCES}

Burger, D. 1980a. Palynology of the Lower Cretaceous in the Surat. Basin. Aus. Bur. Min. Res., Bull., 189, 1-48.

Burger, D. 1980b. Early Cretaceous (Neocomian) Microplankton from the Carpentaria Basin, northern Queensland. Alcheringa, 4, 263-279.

Cookson, I. C. \& Eisenack, A. 1961. Upper Cretaceous Microplankton from the Belfast No. 4 Bore, south-western Victoria. Royal Soc. Victoria Proc., 74, 69-76.

Cookson, I. C. \& Eisenack, A. 1962. Additional Microplankton from Australian Cretaceous sediments. Micropaleontology, New York, 8, 485-507.

Davey, R. J. 1982. Dinocyst stratigraphy of the latest Jurassic to Early Cretaceous of the Holdager No. 1 bore-hole, Denmark. Geol. Surv. Denmark, Ser. B, No. 6, 1-57.

Davey, R. J. \& Verdier, J.P. 1973. An investigation of microplankton assemblages from the Albian of the Paris Basin. Koninkl. Nederlandse Akad. Wetensch. Verh., Afd. Natuurk., Eerste Reeks., 26, 1-58.

Evitt, W. R. 1967. Dinoflagellate studies, II. The archeopyle. Stanf. Univ. Publ. Geol. Sci., Stanford, 10(3), 1-83.

Gitmez, G.J. 1970. Dinoflagellate cysts and acritarchs from the basal Kimmeridgian (Upper Jurassic) of England, Scotland and France. Bull. Br. Mus. Nat. Hist., London (Geol.), 18, 231-331.

Habib, D. 1972. Dinoflagellate stratigraphy Leg 11, Deep Sea Drilling Project, in Hollister, C. D., Ewing, J. I. et al., Initial Reports of the Deep Sea Drilling Project., 11, 367-425.
Helby, R. J. \& Partridge, A. D. 1980. A catalogue of $35 \mathrm{~mm}$ transparencies of Australian Mesozoic dinoflagellate and acritarch species described by I. C. Cookson and co-workers. 1955-1974, R. Morgan 1975-1980 and J. Filatoff 1975. The Earth Resources Foundation, University of Sydney.

Jain, K.P. \& Taugourdeau-Lantz, J. 1973. Palynology of Dalmiapuram grey shale, Dalmaipuram Formation, District Trichinopoly, South India. 1. Taxonomy. Geophytology., $52-68$.

Lentin, J. K. \& Williams, G. L. 1976. A monograph of fossil peridinioid dinoflagellate cysts. Bedford Inst. Oceanography Rept., BI-R-75-16, 1-237.

Mehrotra, N. C. \& Sarjeant, W. A. S. In Press. Dingodinium, a dinoflagellate cyst genus exhibiting variation in archeopyle character.

Norris, G. 1978. Phylogeny and a revised supra-generic classification for Triassic-Quaternary organic-walled dinoflagellate cysts (Pyrrhophyta). Part II. Families and sub-orders of fossil dinoflagellates. N. Jb. Geol. Paläont. Abh. No. 156, $1-30$.

Stover, L. E. \& Evitt, W. R. 1978. Analysis of Pre-Pleistocene organic-walled dinoflagellate cysts. Stanf. Univ. Publ. Geol. Sci., Stanford, U.S.A. 15, 300 pp.

Vozzhennikova, T. F. 1967. Iskopaemye peridinei Yurskikh, Melovykh i Paleogenovykh otlozhenii SSSR. Akad. Nauk. SSSR, Sib. Otd., Inst. Geol. Geofiz., 347 pp. 